\title{
ARHGAP22 Gene
}

National Cancer Institute

\section{Source}

National Cancer Institute. ARHGAP22 Gene. NCI Thesaurus. Code C131764.

This gene plays a role in RAC1 activation. 